
Annals of
Nutrition and
Metabolism

Ann Nutr Metab 2021;77(suppl 3):1-2

DOI: 10.1159/000519223
Received: August 24, 2021

Accepted: August 24, 2021

Published online: September 10, 2021

\title{
Gut Microbiota: No Longer the Forgotten Organ
}

\section{Hania Szajewska}

The Department of Paediatrics, The Medical University of Warsaw, Warsaw, Poland

While the gut microbiota was once called "the forgotten organ" [1], it is no longer forgotten. On the contrary, it is a hot topic for research, as documented by the rapidly increasing number of scientific papers on this subject as well as coverage in the lay press, TV/radio programs, and social media.

The aim of this new series is to highlight recent developments and hot topics in gut microbiome/microbiota research. These two terms are often used interchangeably. However, there is a subtle difference between them [2]. The term microbiome refers to all the microorganisms (and their genes) living in a specific environment such as the gut. These microorganisms include bacteria, archaea, eukaryotes, and viruses. The term microbiota, in principle, refers to the microbes themselves. If only the genes are of interest, the term metagenome is used.

Regardless of the terminology, a balanced gut microbiota is crucial for health. Conversely, dysbiosis, which refers to altered gut microbiota diversity and composition (i.e., changes at the level of phylum, genus, or species) [3], contributes to the development of gastrointestinal and extraintestinal diseases. Among others, the microbiota mediates colonization resistance and influences susceptibility to infectious diseases. The first paper, by Colin Hill [4] from the APC Microbiome Ireland and School of Microbiology, University College Cork, Ireland, reviews advances in the research on infections and the microbiome, which provides a barrier to infection but can also serve as a source of novel antimicrobials. He also introduces the concept of "selective depletion," where pathogens can be reduced by narrow-spectrum inhibitors, such as bacteriocins or bacteriophages (phages). The microbiome is protected and can play a role in reducing the spread of infection by suppressing the growth of pathogens.

The mode of delivery affects the gut microbiome. The World Health Organization estimates the cesarean section rate as $10-15 \%$ of all births if only used when medically necessary. However, cesarean delivery is increasing in prevalence worldwide. Based on data from 169 countries that included over $98 \%$ of births worldwide, cesarean section almost doubled in 2015 compared with 2000 (21.1\% vs. 12.1\%, respectively) [5]. The second paper by Katri Korpela [6] from the University of Helsinki, Finland, discusses the impact of delivery mode on the infant gut microbiota, its consequences, and the interventions to restore the microbial dysbiosis created by cesarean section.

Diet is a key factor that has a substantial impact on the composition and function of the gut microbiota. The third paper, written by Martin Laursen [7] from the National Food Institute, Technical University of Denmark, covers the most important factors controlling the succession and establishment of the gut microbiota in infants after birth. Considering how the early-life gut microbiota impacts our immunity, a better understanding of the process could potentially lead to strategies modifying the risk of diseases later in life. karger@karger.com

www.karger.com/anm (c) 2021 S. Karger AG, Basel

\section{Karger $\stackrel{2}{=}$}

Correspondence to:

Hania Szajewska, hszajewska @ wum.edu.pl 
Some children have too little to eat, while others consume too many calories via junk food and beverages. Consequently, malnutrition consisting of undernutrition, overweight, and obesity is a major public health concern affecting all countries - low-, middle-, and high-income - although in different proportions [8, 9]. In the fourth paper written by Michelle McGuire and Mark McGuire [10] from the University of Idaho, Moscow, ID, USA, the authors discuss data linking the com-

\section{References}

1 Marchesi JR, Adams DH, Fava F, Hermes GD, Hirschfield GM, Hold $G$, et al. The gut microbiota and host health: a new clinical frontier. Gut. 2016 Feb;65(2):330-9.

2 Quigley EM, Ghoshal UC, editors. WGO Handbook on the Gut Microbiome. World Gastroenterology Organisation; 2020 [cited Aug 22, 2021]. Available from: https://www.worldgastroenterology. org/wgo-foundation/wdhd/wdhd-2020/tools-andresources\#Handbook.

3 Hooks KB, O'Malley MA. Dysbiosis and Its Discontents. MBio. 2017 Oct; 8(5):e01492-17.

4 Hill C. Microbiome and infection: a case for "selective depletion". Ann Nutr Metab. doi: 10.1159/000516399.

5 Boerma T, Ronsmans C, Melesse DY, Barros AJD, Barros FC, Juan L, et al. Global epidemiology of use of and disparities in caesarean sections. Lancet. 2018 Oct;392(10155):1341-48. position of the gut microbiota and the regulation of body weight.

In summary, gut microbiome/microbiota research is a hot topic and is booming. This series also documents that the gut microbiota is indeed no longer forgotten and is increasingly recognized as a potential key player in the pathogenesis of several diseases.

6 Korpela K. Impact of delivery mode on infant gut microbiota. Ann Nutr Metab. doi: 10.1159/000518498.

7 Laursen MF. Gut Microbiota development: influence of diet from infancy to toddlerhood. Ann Nutr Metab. doi: 10.1159/000517912.

8 Hawkes C, Ruel MT, Salm L, Sinclair B, Branca F. Double-duty actions: seizing programme and policy opportunities to address malnutrition in all its forms. Lancet. 2020 Jan;395(10218):142-55. Erratum in: Lancet. 2020 Feb 1;395.

9 The double burden of malnutrition. Lancet. Dec 16, 2019 [cited Aug 22, 2021]. Available from: https://www.thelancet.com/series/ double-burden-malnutrition.

10 McGuire MK, McGuire MA. Microbiomes and childhood malnutrition: what is the evidence? Ann Nutr Metab. doi: 10.1159/ 000519001. 